\title{
発泡プラスチック系断熱材の水 ANALYTICAL METHODS OF 分による劣化の分析手法に関す る研究 FOAMED PLASTIC INSULATION DETERIORATED BY WATER
}

\section{任 裕彬— $* 1$ 北垣亮馬 — $* 2$}

キーワード :

断熱材，吸放湿性，膨潤比，水分分布

Keywords:

Insulation, Moisture absorption and desorption, Swelling ratio, Water distribution
Yoobin LEEM

Ryoma KITAGAKI —— $* 2$

Foamed plastic insulations installed into buildings are now expected to be long-lasting materials. However, in recent years, it has been reported that the foamed plastic insulation installed in the high-humid environment, such as under waterproof sheets on a rooftop, absorbs moisture and subsequently increases the thermal conductivity. The mechanism of moisture absorption is not sufficiently clear, and the test method for thermal conductivity of building insulating materials does not consider the influence of humidity. This study observed both moisture absorption and changes of physical properties of foamed plastic insulations after exposed at high humidity and discussed the moisture-induced deterioration.

\section{1. はじめに}

発泡プラスチック系断熱材（以下、発プラ断熱材）は、これまでの 研究や実態調査結果から、長期性能に優れた長持ちする建築材料で あることが報告されている。そして、近年では、新設住宅における「建 築物省エネ法」1) や省エネ観点からの長期優良住宅、サステナブルの 観点からの LCCM 住宅などの政策が進められている。また、既存住宅 改修における評価手法の検証 ${ }^{2)}$ 、低炭素化、省エネ、建築物の長寿命 化と共に、ますます断熱材の長期性能が求められてきている。

しかし、近年、発プラ断熱材は、屋上防水層下など高湿度環境であ ると吸水する、発プラ断熱材は経年により内部ガスが放出され熱伝 導率が変化するといったことが報告されてきている3)。加えて、恒温 恒湿槽内に暴露し、暴露時間の違いや恒温恒湿槽内の温湿度条件の 違いによる発プラ断熱材の寸法や重量の変化があることが報告され ている4)。

こうした変化の際に、発プラ断熱材の変化は目視や顕微鏡画像を 用いてもほとんど見られないため、その原因は十分明らかにされて いない5)。さらに、ISO 115616) や JIS A 14867) による解析モデルは 湿度による変化を考慮していない。

そこで、本報告の目的は、発プラ断熱材の経年変化のうち、水分に 関する変化とそのメカニズムを明らかにするために、基礎的考察と して、高分子物理学的手法を援用した分析手法を援用し、様々な環境 条件において水分が発プラ断熱材の長期性能の一つである熱伝導率 の維持にどのような影響を与えるのかを検討することを目的とする。

具体的には、まず、X 線 CT から得られたデータを 3 次元画像解析 を用いることによって、連続気泡構造の発泡体であるポリウレタン フォームの空隙分布と Strut を定量的に評価する方法を検討した既 往の研究8) を参考に、独立気泡構造であるその他の発プラ断熱材にお いても同様の分析手法が適用可能かを検討寸る。続いて、高湿度一液 水浸漬サイクル条件下の発プラ断熱材に着目し、同じくX 線 CT から
得られたデータから水分分布を構築するとともに、高分子の膨潤比 を測定することで、吸水による高分子ゲル構造の変化を評価する。

さらに、恒温での高湿度一低湿度サイクル条件ならびに恒温恒湿 条件での熱伝導率の経時測定、吸湿による熱伝導率の変化から、発プ ラ断熱材の物性上の変化が見られるかについて検討する。以上を通 じて、水分状態の異なるさまざまな環境に暴露された発プラ断熱材 の状態変化を各種の測定手法で評価することで、水分が発プラ断熱 材へおよぼす影響を考察するものとする。

\section{2. 実験}

\section{1 サンプルの調整}

本報告における各実験では、サンプルとして Table 1 に示す押出 法ポリスチレンフォーム (XPS)、ポリウレタンフォーム (PUF)、フェ ノールフォーム $(\mathrm{PF})$ の各品種を用いた。PUF および PF は 1 品種の みを用い、XPS については、後述する 2.4 節の実験が他の実験に比心゙ てかなり長期間の暴露日数（300 日程度）となることから、この実験 のみ内部ガス放出が比較的早い段階で平衡となる XPS1bC を用いた。 また以降の品種の表記についてはサンプルとしてXPS1bCを用いる場 合にはこれを表記し、ほかは一般名であるXPS、PUF、PFを用いた。 サンプルの調整に関して、一般的に発泡プラスチック系断熱材は、 内部ガスの放出などの影響により、数日〜数週間の間に熱伝導率が 変化することが指摘されている。そこで本報告では、製造時から一般 的な製品倉庫に数週間存置した断熱材の中央付近を切り出したもの を、後述の各節の実験条件に従ったサンプル形状に加工した上で、1 日間 JIS A 9521 に準じた $\left(23^{\circ} \mathrm{CRH} 50 \%\right)$ 環境に存置してから、実験 に供するようにした。そして、一つの断熱材から切り出されたサンプ ルを水分への暴露状態が異なる環境におくことで得られた実験結果 から、水分による作用の違いを考察するようにした。この際、水分へ の暴露状態の違いによって、まだ残留している内部ガスによる影響
'1 北海道大学工学院空間性能システム専攻 大学院生

(宁 060-8628 札幌市北区北 13 条西 8 丁目)

2 北海道大学工学院空間性能システム専攻 准教授
Master Student, Division of Human Environmental System, Hokkaido Univ.

Assoc. Prof., Division of Human Environmental System, Hokkaido Univ. 
が変化し、異なる結果を生じる場合もあると思われるが、それも含め て水分の作用として考察した。

\section{$2.2 X$ 線 CT による発プラ断熱材の空隙分布測定手法の構築}

発プラ断熱材の水分分布を得るためには、事前に発プラ断熱材の 空隙分布を評価する必要がある。そこで、X 線 CT によって乾燥状態 の発プラ断熱材の空隙分布を測定し、その妥当性を検討する。サンプ ルとしては、 $20^{\circ} \mathrm{CRH} 0 \%$ の状態で 2 週間保持した押出法ポリスチレン フォーム（XPS）を用いた。

Table 2 に測定に用いた X 線 CT の詳細を示す。X 線 CT によって得 られた結果は付属の画像解析ソフトウェア（Bruker CTAn および CTvox）により 3 次元データとして再構築した。設定に関する詳細を Table 3 に示す。

\section{3 高湿度一液水浸漬サイクルによる吸水性と膨潤比による高分子 ゲル構造評価}

\section{3.1 試験体の作製およびサイクル条件の設定}

Fig. 1にサンプルの概要を示す。材料には、XPS、PUF、PF を用い た。サンプルサイズは $10 \mathrm{~mm} \times 10 \mathrm{~mm} \times \mathrm{t} 5 \mathrm{~mm}$ とし、表層に被覆材がな いXPS については表層から所定の大きさに切り出したものを利用し た。表層に被覆材がある PUF と PF については、被覆材の有無による 影響を調べるために、表層から厚さ $10 \mathrm{~mm}$ 部分を取り出し、厚さ方向 に $5 \mathrm{~mm}$ ずつ 2 分割になるようにスライス寸ることで厚さ方向に性質 の異なる 2 体のサンプルを得た。建築物に施工された断熱材の小口 面および一つの表層面から水分が浸入する場合を想定して、XPS では 底面に、PUF とPFについてはスライス面にアルミテープを貼付け、 貼付面以外は小口面を含め露出させたままとした。既往の研究9)によ ると、屋上防水層下に施工された断熱材であっても、経年により高い 吸水率の発プラ断熱材が発見されたことが報告されている。また、通 気筒がある場合であっても、基材であるコンクリートと防水層に挟 まれて常に高湿度環境下にあることが多いものと考えられる ${ }^{10)} 。 さ$ らに、経年劣化した防水層においては、その一部が切れて雨水が侵入 する場合も想定されうる。そこで、高湿度一液浸漬サイクルによる促 進劣化試験を実施することとした。

実際の建築物に施工された断熱材において、小口面と表面が同時 に高湿度環境や液水に暴露される状況は、かなり過酷な環境と考え られるが、促進劣化試験の観点から、このような仕様に設定した。

上記のサンプルをアルミテープの施工されていない面を上にする ようにして $50^{\circ} \mathrm{CRH} 90 \%$ の温湿度環境で 3 日保持後、 $20^{\circ} \mathrm{C}$ の水に 1 日 浸漬させるサイクルを 3 サイクル繰り返す劣化試験を実施した。浸 漬中はサンプルが浮き上がるのを防ぐために重りを乗せた。また比 較のためにサイクル試験を実施しないサンプルも用意した。

\section{2. $3.2 X$ 線 CT による水分分布測定}

既往の研究 ${ }^{11)}$ に基づき、促進暴露試験による劣化/未劣化の断熱材 の水分分布を測定するために、 X 線 CT によって得られた濃淡画像と サンプルの含水率から、内部の水分分布を得る測定手法を検証した。 X 線 CT は $130 \mathrm{kV} 、 70 \mu \mathrm{A} 、$ スライスピッチ $0.015 \mathrm{~mm} 、 1$ 枚撮影当たり露 光時間 $250 \mathrm{msec}$ の条件で断面画像を撮影した。得られた濃淡画像の 一部を Fig. 2 に示寸。その X 線 CT 画像から、乾燥状態のサンプル では観察されない表層部分の水分に相当する明度をしきい值（明度 $160\{\mathrm{PF}$ (1 層目)、PUF (2 層目)、XPS $\} 、 140\{\mathrm{PF}$ (2 層目)、PUF（1 層目) \}）として用いて 2 值化したうえで、サンプル全体の体積含水率
とスライス画像の白点の面積を積分して得られた白点の体積占有率 から、白点 1 画素あたりの体積含水率を算定し、厚さ方向に変換し たサンプルの水分分布を求めた。

\section{3.3 膨潤比評価}

膨潤比は、次の操作で評価した。測定前処理として、試験体を $40^{\circ} \mathrm{C}$ の恒温槽に入れ、1 日間乾燥させた。その後、エタノールに浸漬させ、 エタノールによる膨潤を測定した。浸漬後の $0 、 24 、 48 、 72 、 96$ 時間 後の質量及び体積を測定した。この評価において、未劣化の試験体は 試験体-na、劣化の試験体は試験体-a と名称寸る。体積 V は、比重計 を用いて、サンプル体積の概ね 100 倍の目安としたエタノール溶媒 に浸漬して測定した。測定は $20^{\circ} \mathrm{C}$ 暗室で行った。エタノール浸漬 時間 $\mathrm{t}$ 毎の膨潤比 $Q_{\mathrm{t}}$ は、エタノールによる膨潤操作前の体積 $\mathrm{V}_{\mathrm{o}}$ と膨 潤体積 $V_{\mathrm{t}}$ から式（1）により算出した ${ }^{12)}$ 。(発プラ断熱材がエタノー ルに沈まないため、断熱材の上に重りを乗せて膨潤比測定を行った。)

$$
\mathbf{Q}_{t}=V_{t} / V_{0}
$$

\section{4 高湿度一低湿度サイクルによる熱伝導率の経時変化}

2.3 節で高湿度一液水浸漬サイクルを評価することに加えて、高湿 度一低湿度サイクル負荷における評価を実施した。ただし、この評価 では、X 線 CT や顕微鏡によって観測できる液水の凝縮がほとんどな いことが考えられることから、相対湿度の環境変化に及ぼす断熱性 能への影響を測定することを目的として、熱伝導率が測定できる厚 さに変えて測定を行った。試験体は 2.3 節で対比的な結果が得られ た基材が疎水性であるXPS の 1 品質であるXPS1bC と親水性のPF を 用いた。本実験は本報告の他の実験に比べてかなり長期間の暴露日 数（300 日程度）となることから、この実験のみ内部ガス放出が比較 的早い段階で平衡となる XPS1bC を用いた。試験サイクルは、 $23^{\circ} \mathrm{C}$ 、 相対湿度 $90 \%$ で 30 日間 $\Rightarrow 50 \%$ で 230 日間 $\Rightarrow 90 \%$ で 30 日間の湿度市 イクル負荷を与え断熱性の変化を測定した。相対湿度 $90 \%$ は、XS1bC 及びPF が使用される床下湿度の環境を想定した ${ }^{13) 、 14) 。 ~}$

サイクル試験に供するサンプル調整のために、まず、厚さが $45 \mathrm{~mm}$ の製品 PF（被覆材あり）と製品 XPS1bC から、200 mm×200 mm× t45 $\mathrm{mm}$ のサイズを切り出した。そして、暴露環境からの負荷促進のために $45 \mathrm{~mm}$ の厚さを 4 等分するようにスライスし、スライスされたサンプ ルが試験を行う環境槽内で重ならないように、下面も空気が通過す る網状のステージに並べてからサイクル試験を開始した。

そして、各発プラ断熱材の熱伝導率の測定においては、もともと一 体であった同じ材質のスライスサンプル 4 枚をスライス前の状態に なるように一体に重ね、JIS A 1412-2 ${ }^{15}$ の測定条件に準じて 4 枚一 体となった発プラ断熱材の熱伝導率を測定した。熱伝導率の測定時 期として、サイクル試験開始直前、 $23^{\circ} \mathrm{CRH} 90 \%$ の高湿度暴露期間中に 10 日間隔、 $23{ }^{\circ} \mathrm{CRH} 50 \%$ 低湿度暴露期間中に期間開始直後と期間終了 直後で測定を行い、初期熱抵抗值 $R_{0}$ 及び任意の経過時間における熱 抵抗 $R_{t}$ は 4 枚一体で測定した值を用いて算出し、そこから相対熱抵 抗比を得た。測定機器は、適正に校正されたものを用いた。

\section{5 恒温恒湿条件の長期継続による吸湿性と熱伝導率の経時変化 2. 5. 1 恒温恒湿条件の長期継続における含水率の経時変化} 現在、JIS A 1486 に基づく発泡プラスチック系断熱材の長期性能評 価試験においては、湿度範囲を RH $50-10 \%+20 \%$ としてもよい、とし ている。一方で、実際には発泡プラスチック断熱材の設置される環境 
として、より高湿度に長期暴露されることも十分考えられる。湿度環 境が熱伝導率の長期性能を変える可能性があることから、XPS、PF に ついてそれぞれ表層材のない $5 \mathrm{~cm}$ 角の立方体をJIS A 1475 ${ }^{16)}$ に基つ き、飽和塩によるデシケーターを用いて、 $23^{\circ} \mathrm{CRH} 53 \% 、 75 \% 、 81 \% 、 85 \%$ 、 93\%における平衡含水率曲線を測定した。吸湿過程におけるサンプル は前処理養生として、 $70 \pm 2{ }^{\circ} \mathrm{C} の$ 基準温度で乾燥調整し、放湿過程用 サンプルは $23^{\circ} \mathrm{CRH} 95 \%$ のデシケーター内で調整した後、所定のデシ ケーターに入れ、JIS A 1475 に基づき、24 時間間隔で測定した連続 する 3 回の測定の質量変化が試料の質量の 0.1 \%以下となった時点 を恒量として平衡含水率を測定した。サンプルは各条件にて 3 体ず つ測定し平均值を評価した。

\section{5.2 恒温恒湿条件の長期継続における熱伝導率の経時変化}

本節では、所定の湿度条件に存置された発プラ断熱材が吸湿過程 から平衡含水率に到達するまでの過渡的な熱伝導率の推移を評価す るため、XPS、PF を $200 \mathrm{~mm} \times 200 \mathrm{~mm} \times \mathrm{t} 10 \mathrm{~mm}$ の寸法にそろえ、2.1 節に 基づき初期状態に養生した上で、開始直前のサンプル重量、熱伝導率、 初期熱抵抗 $R_{0}$ を JIS A 1412-2 に基づいて算定した。その後、JIS A 1486 の湿度範囲である $23^{\circ} \mathrm{CRH} 50 \%$ 及び $23^{\circ} \mathrm{CRH} 70 \%$ に存置しながら 定期的に重量および熱伝導率を測定し、吸湿過程における平衡含水 率に達するまでの過渡的な熱伝導率の変化を測定した。この実験は、 ガス抜けによる熱伝導率の変化を評価することを想定した JIS A 1486 の長期性能の評価試験方法を参考にしているが、吸湿過程にお ける熱伝導率の変化を評価するため重量変化も同時に測定する。XPS の測定時期は開始から 1、3、6、10、15、21、28 日の時点であり、PF に関しては、42、56 日後の時点も測定を行った。

\section{3. 結果と考察}

\subsection{X 線 CT による発プラ断熱材の空隙分布}

2.2 節で実施した結果を以下に示寸。XPS の構造体のサイズによる 体積分布をFig. 3、XPS の空隙のサイズによる体積分布をFig. 4 と XPS の構造体を 3D 化したものをFig. 5 に示す。セル膜厚さ $3.0 \sim 5.0$ $\mu \mathrm{m}$ の体積比が一番大きく、セル径に相当する断面寸法は、 $90 \sim 120$ $\mu \mathrm{m}$ のゾーンの体積比が大きく、小さい寸法側に分布している特徵が 観察された。試験結果から、X 線 CT による空隙分布測定は断熱材を 詳細に把握できる手法を確認できた。

\section{2 高湿度一液水浸漬サイクルによる吸水性と膨潤比による高分子 ゲル構造評価}

\section{2.1 X 線 CT による水分分布}

2.3.2 節で実施した結果を Fig. 6 に示す。縦軸は表面からの厚さ 方向の距離を示し、 $0 \mathrm{~mm}$ および $5 \mathrm{~mm}$ の部分にある材料(アルミテープ、 被覆材、被覆材なし）を記載した。Fig. 6 から、どの断熱材の実験 体も表面から $1 \mathrm{~mm}$ の深さまで高明度の画像が分布していることが確 認できる。すなわち、水分が表面から $1 \mathrm{~mm}$ の深さまでは広く分布し ていると考えられる。このことは、アルミテープを張っている表面か らも観察できるが、アルミテープの接着剤が高明度に表示されるこ とに関する検証が要ると考えられる。

PF は他の断熱材と比べ、断熱材の内部まで水分が広く分布してい ることが確認できる。PF（1 層目）は、中心付近の含水率が最低でも 20\%より大きくなり、また、PF（2 層目）の場合は $70 \%$ より大きくな った。1 層目と 2 層目の含水率の違いは断熱材の表層材の有無によっ
て生じたと考えられる。一方、XPS と PUF の中心付近の含水率は $10 \%$ より小さかった。

\section{2.2 膨潤比評価}

2.3 .3 節で実施した劣化/未劣化の発プラ断熱材試験体の膨潤の結 果をFig. 7 に示寸。PUF の膨潤比は、劣化/未劣化によらず、また 1 層目 $/ 2$ 層目によらず、 1.15 から 1.20 の範囲に值が収束しているこ とが確認できる。また、XPS についても、劣化/未劣化によらず 1.08 付近の数值を示している。一方で、PF は未劣化の状態では、 1 層目 $/ 2$ 層目によらず、1.05 から 1.10 の範囲に値が収束しているにもかかわ

Table 1 Types of samples

\begin{tabular}{|c|c|c|}
\hline Symbol & \multicolumn{2}{|c|}{ Types } \\
\hline $\mathrm{XPS}_{\left.\mathrm{b} \mathrm{b}^{*}\right)}$ & \multicolumn{2}{|c|}{ Extruded polystyrene insulation $\left.3 \mathrm{bA}^{*}\right)$} \\
\hline XPS1bC $\left.{ }^{*}\right)$ & \multicolumn{2}{|c|}{ Extruded polystyrene insulation $\left.1 \mathrm{bC}^{*}\right)$} \\
\hline PUF-B & \multicolumn{2}{|c|}{ Polyurethane foam insulation with surfacing material } \\
\hline PF1.3C II $\left.{ }^{*}\right)$ & \multicolumn{2}{|c|}{ Phenolic foam insulation $1.3 \mathrm{C}$ II with surfacing material $\left.{ }^{*}\right)$} \\
\hline \multicolumn{3}{|c|}{ "Products labelled with "JIS mark" certified by JIS A 9521} \\
\hline \multicolumn{3}{|c|}{ Table 2 Scanner Settings } \\
\hline \multicolumn{2}{|c|}{ Parameter (Unit) } & Value \\
\hline \multicolumn{2}{|c|}{ X-ray source voltage applied(kV) } & 30 \\
\hline \multicolumn{2}{|c|}{ X-ray source resulting current $(\mu \mathrm{A})$} & 401 \\
\hline \multicolumn{2}{|c|}{ X-ray detector binning } & $1 \times 1$ \\
\hline \multicolumn{2}{|c|}{ Number of rows on camera matrix } & 2688 \\
\hline \multicolumn{2}{|c|}{ Number of columns on camera matrix } & 4032 \\
\hline \multicolumn{2}{|r|}{ filters } & Not activated \\
\hline \multicolumn{2}{|c|}{ Flat field correction } & On \\
\hline \multicolumn{2}{|c|}{ Use 360 rotation } & Not activated \\
\hline \multicolumn{2}{|c|}{ Camera offset mode } & Not activated \\
\hline \multicolumn{2}{|c|}{ Number of connected scans per step } & 1 \\
\hline \multicolumn{2}{|c|}{ Rotation step(deg) } & 0.2 \\
\hline \multicolumn{2}{|c|}{ Exposer time (ms) } & 3100 \\
\hline \multicolumn{2}{|c|}{ Image pixel size $(\mu \mathrm{m})$} & 1 \\
\hline \multicolumn{2}{|c|}{ Output files type } & 16-bit TIFF \\
\hline
\end{tabular}

Table 3 Software settings for 3D image analysis

\begin{tabular}{l|c}
\multicolumn{1}{c}{ Parameter (Unit) } & Value \\
\hline Image pixel $(\mu \mathrm{m})$ & 1 \\
\hline 3D image voxel dimensions $(\mu \mathrm{m})$ & $1 \times 1 \times 1$ \\
\hline ROI reference length & 4032 \\
\hline First section number & 172 \\
\hline Last section number & 2527 \\
\hline Sections count & 2356 \\
\hline $\begin{array}{l}\text { 3D cross sectional image stack dimensions } \\
\text { (diameter; height) }(\text { mm) }\end{array}$ & $1 ; 1$ \\
\hline 3D stack files type & BMP \\
\hline Thresholding & Using Ohtsu \\
\hline Despeckle & White speckles \\
\hline - Type of item to remove from 3D space & 10 \\
\hline - max speckle volume (voxels) &
\end{tabular}
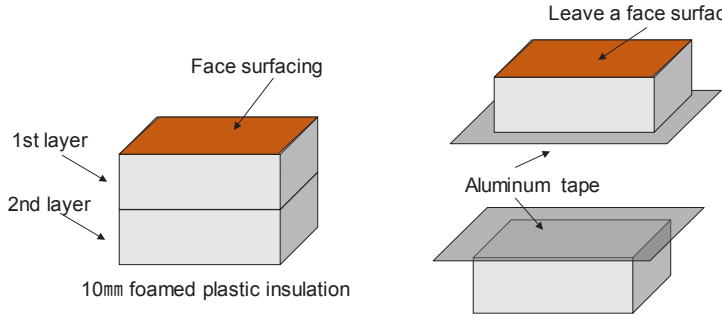

1st layer

2nd layer

Fig. 1 High humidity-immersion cycle specimens

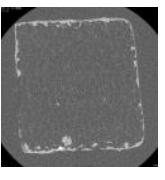

XPS

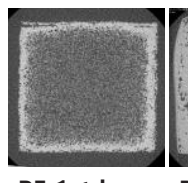

PF 1st layer PF 2nd layer PUF 1st layer PUF 2nd layer specimens by $\mathrm{CT}$ 
らず、劣化後には、1 層目が 1.26、2 層目が 1.48 となっている。他 の断熱材に比心゙、高湿度一液水浸漬サイクルの影響により、膨潤比が 大きく変化していることが確認された。PF の劣化前後の膨潤比の差 が 1 層目と 2 層目の試験体に全て現れたことから、試験体中の高分 子ゲル構造において、分子間力などの高分子ゲル間の総合作用が減 少したことが分かる。そこから、劣化時試験体の内部に浸透する水蒸 気が内部のゲル構造や結合状態を変化させたと考えられる。加えて、 PF の 1 層目より 2 層目が澎潤比の差が大きいことは表層材の有無に よる結果だと考えられる。

\section{3 高湿度一低湿度サイクル試験における熱伝導率の経時変化}

2.4 節で実施したル高湿度一低湿度サイクル試験における相対熱抵 抗比の経時変化をFig. 8 に、その際の熱伝導率と熱抵抗の経時変化 をTable 4 に示す。相対熱抵抗比は、もともと一体であった同じ材 質のスライスサンプル 4 枚をスライス前の状態になるように一体に 重初て測定された熱伝導率から算出した。XPS1bC の相対熱抵抗比の 低下は、湿度サイクル負荷の条件にかかわらず、経過時間とともに安 定する傾向が測定された。PFの相対熱抵抗比は、相対湿度 90\%負荷 中に大きく低下し、相対湿度 $50 \%$ に戻すと回復する傾向が確認され た。加えて、相対湿度 $90 \%$ の 1 回目と 2 回目との比較では、2 回目 の相対熱抵抗比の方がさらに小さくなる傾向が確認された。湿度サ イクル負荷において不可逆の傾向にある PF の相対熱抵抗比の変動は、

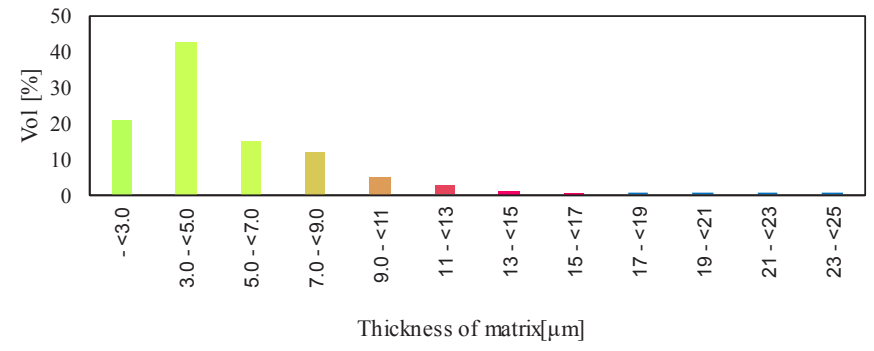

Fig. 3 Volume distribution by thickness of matrix of XPS

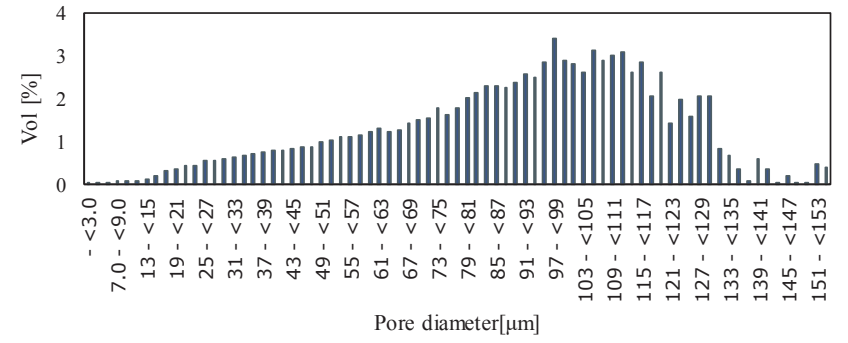

Fig. 4 Volume distribution by pore size of XPS

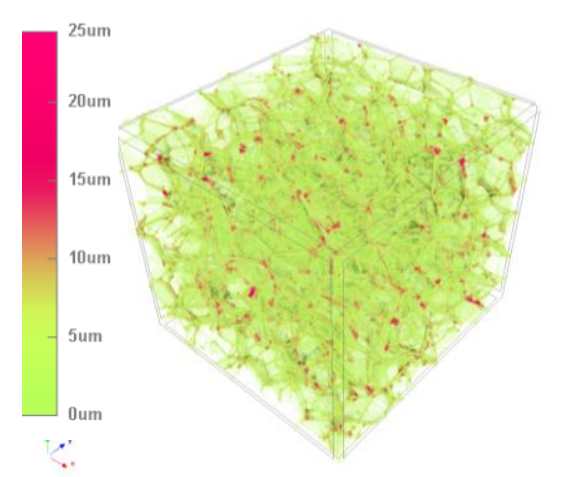

Fig. 5 3D XPS structure (Cell membrane thickness)
吸放湿による水分変動と樹脂性状変化による蓄水量以外の要因が複 合していることが考えられる。

\section{4 恒温恒湿条件の長期継続による吸湿性と熱伝導率の経時変化}

\section{4.1 恒温恒湿条件の長期継続における含水率の経時変化}

2.5.1 節で実施した XPS と PF の平衡含水率のデータを Fig. 9 に 示す。XPS は、吸湿過程、放湿過程両方の值が $0.20 \times 10^{-3} \mathrm{~m}^{3} / \mathrm{m}^{3}$ よ り低い值を示した。PF は、相対湿度 70\%を超えると大きくなる傾向 を示した。また、吸湿過程よりも放湿過程の平衡含水率の方が大きく なるヒステリシスが確認されて、蓄水性を有することが確認された。
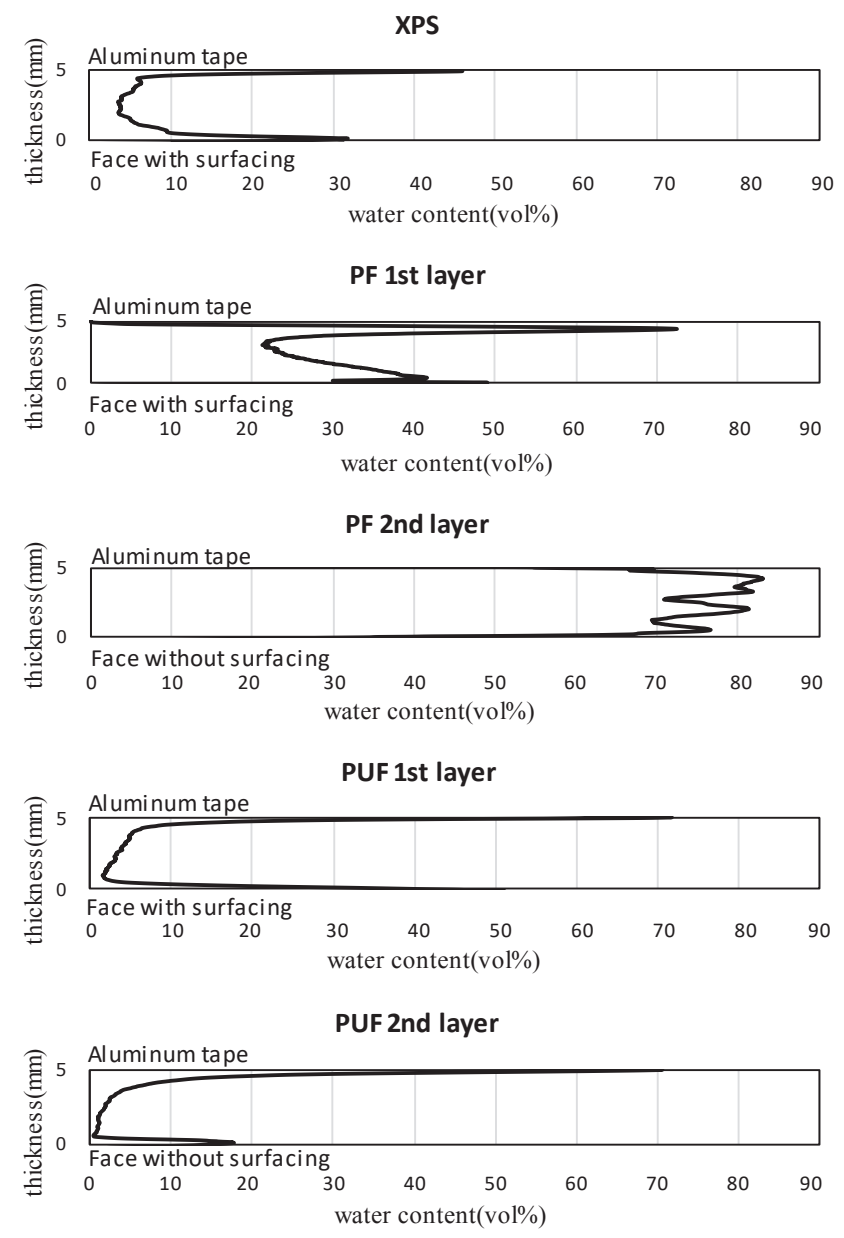

Fig. 6 Water content distribution by thickness of deteriorated

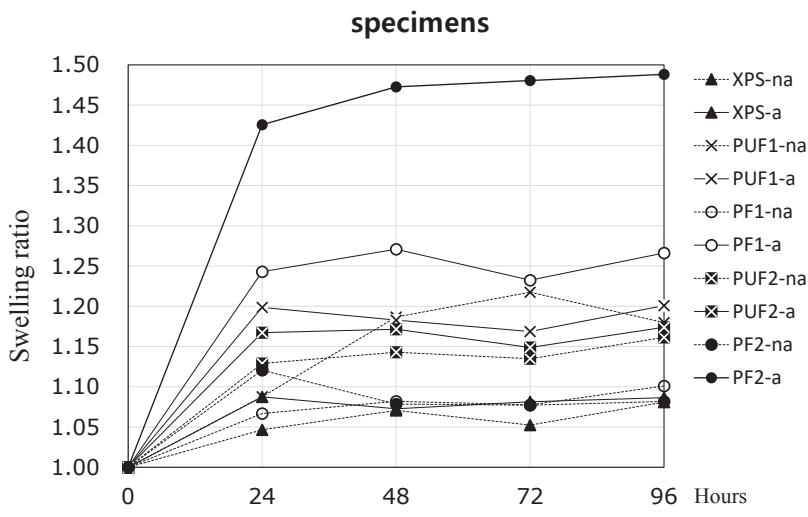

*In the legned, -na(not aging), -a(aging) , PF1-a(PF 1st layer with aging )

Fig. 7 Swelling ratio of specimens 
加えて、JIS A 1475 の恒量基準を満足し吸湿過程における平衡含水 率曲線を得たサンプルをさらに 30 日間継続して同じ湿度環境のデシ ケーターに存置した後に測定した含水率をFig. 10 に示す。Fig. 9 に比べて XPS は含水率がほぼ増加していないと考えられる一方で、 PF は高湿度領域の含水率が大きく増加している。PF の場合、JIS A 1475 の恒量基準を満足し得られた平衡含水率の測定後も徐々に含水 率が増加していることが考えられる。このことは、高湿度環境に長期 間暴露した場合に、PF に材質的な変化が生じている可能性があるこ とを示唆している。一方、短期間で水分暴露条件を変化させた液水浸 漬試験の結果である Fig. 7 において、浸漬試験の有無による PF の 膨潤比は大きく変化しており、水分が PF の高分子構造に変化を与え る因子となると考えられる。液水や高湿度環境におかれる可能性の ある断熱材の使用方法や長期性能の評価のために、断熱材を構成す る材質そのものと水分の間の作用についても検討が必要であると考 えられる。

\section{4. 2 恒温恒湿条件の長期継続における熱伝導率の経時変化}

2.5.2 節で実施した結果として、Table 5 およびFig. 11 に測定日 数による相対熱抵抗比と熱伝導率の経時変化を示す。XPS は相対湿度 $50 \% 、 70 \%$ 両方、0 日から 3 日まで急激な熱伝導率の変化を見せた。 28 日の時点で 0 日との熱伝導率の差が相対湿度 50\%は 0.0039、70\% は 0.0038 であった。加えて、XPS は熱伝導率が約 0.031 に収束され ることが確認できた。その反面、PF は相対湿度 $50 \%$ は 28 日の時点 で熱伝導率の差が 0.0016、70\%の時には 0.0021 であるが、XPS と違 い、熱伝導率がある值に収束されず上がり続けることが確認された。 56 日の時点では 0 日の熱伝導率との差が相対湿度 50\%は 0.0021、 $70 \%$ は 0.0028 であった。そこから、PF は時間とともにその值が増加 し続けることが分かる。その傾向は高湿度になるとともに加速化さ れ、その増加率が高くなった。XPS は高湿度環境に置かれても、熱伝 導率の経時変化が小さくなっていく傾向を示すが、PF は同環境に置 かれると、長期にわたって熱伝導率が上昇し続けた。

Table 4 Change of thermal conductivity \& resistance

\begin{tabular}{|c|c|c|c|c|c|}
\hline \multirow{3}{*}{ Days } & \multirow{3}{*}{ Condition } & \multicolumn{2}{|c|}{ XPS1bC } & \multicolumn{2}{|c|}{$\mathrm{PF}$} \\
\hline & & $\lambda$ & $\mathrm{R}$ & $\lambda$ & $\mathrm{R}$ \\
\hline & & $\mathrm{W} /(\mathrm{m} \cdot \mathrm{K})$ & $\mathrm{m}^{2} \cdot \mathrm{K} / \mathrm{W}$ & $\mathrm{W} /(\mathrm{m} \cdot \mathrm{K})$ & $\mathrm{m}^{2} \cdot \mathrm{K} / \mathrm{W}$ \\
\hline 0 & \multirow{4}{*}{$23^{\circ} \mathrm{C}$ RH $90 \%$} & 0.0334 & 1.21 & 0.0198 & 2.05 \\
\hline 10 & & 0.0345 & 1.17 & 0.0229 & 1.77 \\
\hline 20 & & 0.0347 & 1.17 & 0.0234 & 1.73 \\
\hline 30 & & 0.0349 & 1.16 & 0.0239 & 1.70 \\
\hline 31 & \multirow{2}{*}{$23^{\circ} \mathrm{C}$ RH50\% } & 0.0349 & 1.16 & 0.0227 & 1.78 \\
\hline 260 & & 0.0356 & 1.14 & 0.0233 & 1.74 \\
\hline 270 & \multirow{3}{*}{$23^{\circ} \mathrm{C}$ RH $90 \%$} & 0.0359 & 1.13 & 0.0252 & 1.61 \\
\hline 280 & & 0.0360 & 1.13 & 0.0248 & 1.63 \\
\hline 290 & & 0.0362 & 1.12 & 0.0256 & 1.58 \\
\hline
\end{tabular}

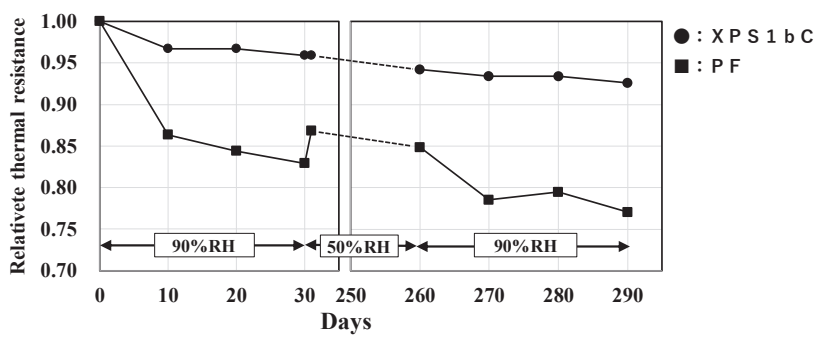

Fig. 8 Change of relative thermal resistance ratio
ここで、Table 4 において内部ガス放出の影響をより少なくした XPS1bC を用い、 $23^{\circ} \mathrm{CRH} 90 \%$ に 30 日間存置した場合の熱伝導率の変化 率と、Table 5 においてXPS3bA を用い $23^{\circ} \mathrm{CRH} 50 \%$ に 28 日間存置し た場合の熱伝導率の変化率を比較すると、後者の変化率が大きい。両 者の単純な比較は困難であるが、XPS 系の断熱材においては熱伝導率 の長期維持に内部ガスの影響が大きい可能性が示唆される。近藤ら ${ }^{17}$ によると、ガス抜けを促進させる高温 $\left(60^{\circ} \mathrm{C}\right)$ 促進暴露試験において、 XPS は最大 $16 \%$ 程度相対熱抵抗比が減少し、PF は $12 \%$ 程度の相対熱 抵抗比が減少し、どちらも概ね収束している。この一方で、同じ高分 子の種類で、高湿度環境を用いた促進暴露試験となっている本実験

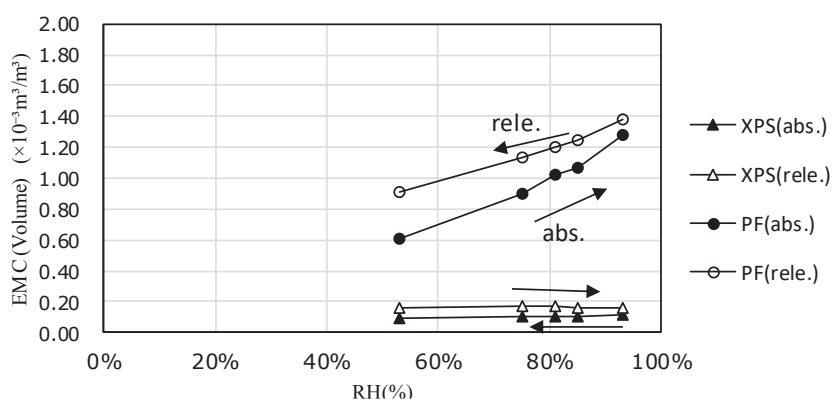

*In the legend, abs.(absorption), rele.(release)

Fig. 9 XPS, PF equilibrium moisture content

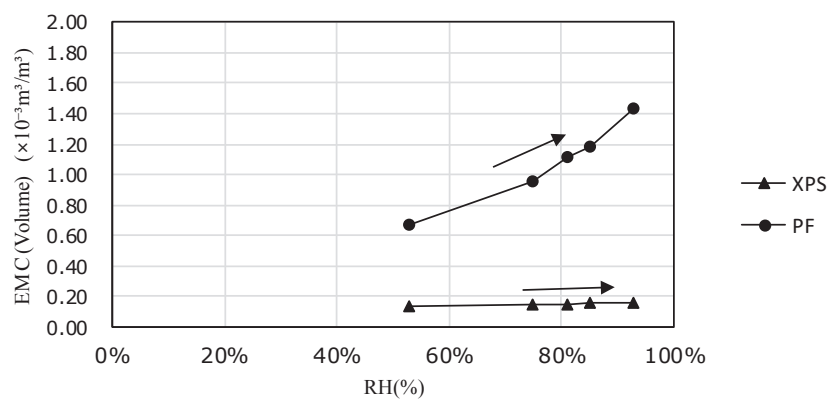

Fig. 10 XPS, PF moisture content(1 month after Fig.9)

Table 5 Thermal conductivity (W/(m $\cdot \mathbf{K}))$

\begin{tabular}{r|r|r|r|r}
\hline Days & $\mathrm{XPS} 23^{\circ} \mathrm{C} 50 \%$ & $\mathrm{XPS} 23^{\circ} \mathrm{C} 70 \%$ & $\mathrm{PF} 23^{\circ} \mathrm{C} 50 \%$ & $\mathrm{PF} 23^{\circ} \mathrm{C} 70 \%$ \\
\hline 0 & 0.0268 & 0.0272 & 0.0205 & 0.0212 \\
\hline 1 & 0.0289 & 0.0296 & 0.0208 & 0.0216 \\
\hline 3 & 0.0300 & 0.0304 & 0.0208 & 0.0217 \\
\hline 6 & 0.0304 & 0.0308 & 0.0212 & 0.0221 \\
\hline 10 & 0.0303 & 0.0308 & 0.0214 & 0.0224 \\
\hline 15 & 0.0304 & 0.0309 & 0.0217 & 0.0227 \\
\hline 21 & 0.0306 & 0.0309 & 0.0217 & 0.0228 \\
\hline 28 & 0.0307 & 0.0310 & 0.0221 & 0.0233 \\
\hline 42 & & & 0.0226 & 0.0237 \\
\hline 56 & & & 0.0229 & 0.0240 \\
\hline
\end{tabular}

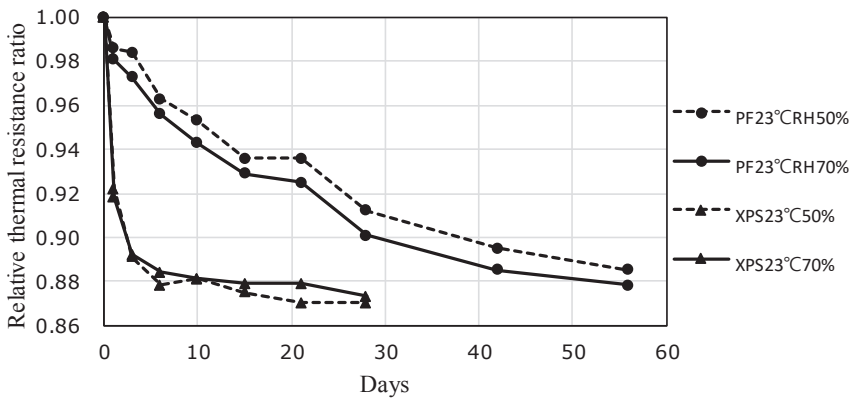

Fig. 11 Relative thermal resistance ratio (XPS, PF) 
では、Fig. 11 に示されるように、 $23^{\circ} \mathrm{CRH} 70 \%$ に設置されたサンプル の終局時の相対熱抵抗比について、XPS は 4 週目に $13 \%$ 程度の減少 でほぼ収束となる一方で、PF は 8 週目に $12 \%$ の減少でも収束して いない傾向を有しているように見える。湿度が加わることで、ガス 抜けのみが想定される場合の熱伝導率の変化とは異なる傾向を示す 結果となっており、高温環境で生じるガス抜けとは異なる現象が生 じている可能性も考えられる。今後は、ガス抜けだけではなく、水 分によるメカニズムが作用し、熱伝導率が変化する可能性を検討す る必要性が指摘される。

\section{4. まとめ}

発泡プラスチック系断熱材を、水分状態の異なるさまざまな環境 (液水、湿潤、乾燥、その繰返し) 条件に存置し、その影響を X 線 CT、膨潤比、熱伝導率といった観点で評価したところ、以下の結論が 得られた。

1） X 線 CT 画像による解析手法の確立により、発プラ断熱材の内部 構造及び内部水分分布の可視化が実現され、メカニズムの考察 に有効であった。

2）液水の吸水への影響については、X 線 CT 画像解析の結果から XPS、PUF は小さいこと、PF は大きいことが観察され、各発プラ 断熱材の膨潤比との関係も示唆された。さらに、高湿度一低湿 度サイクルにおいて、XPS は湿度サイクル条件に関わらず、経 時で低下が進行したが安定した。PF は湿度サイクル条件に連動 して変化しつつ、低下が継続して進行することが観察された。

3）本報告では、発プラ断熱材の水分による変化が高分子の種類に よって大きく異なることが確認され、液水や高湿度環境による 高分子の構造的変化が膨潤比によって観察された。発プラ断熱 材の長期性能の評価において湿度の影響を加味するべきと考 えられる。

本検討によって、発プラ断熱材の種類よっては液水・水蒸気が作用 し、断熱性能に影響を及ぼす一端が明らかとなった。今後の研究とし て、実際の設置環境を想定した種々の環境条件を用意し、熱伝導率を 中心とする発プラ断熱材の長期性能一水分が及ぼす影響を検討する ことが望ましいと考えられる。

\section{参考文献}

1）国交仕様：建築物のエネルギー消費性能の向上に関する法律（平成 27 年 法律第 53 号)、2015.7、入手先〈https://www.mlit.go.jp/jutakukentiku/ jutakukentiku_house_tk4_000103.html>、(参照 2015-07-08)

2）国交省：既存住宅に係る住宅性能の評価手法に関する検討、2014.5、入 手先 $<$ https://www.mlit.go.jp/jutakukentiku/house/jutakukentiku_house_tk4_ 000085.html > 、(参照 2015-02-26)

3) Kondo, Y., et al. : INVESTIGAYION OF FACTORS OF PERFORMANCE CHANGE OF INSULATIONS OF VIBRATION ON THERMAL PERFORMANCE CHANGE Long term thermal performance of building insulation materials Part 1. Journal of Environmental Engineering, Vol. 74, No. 643, pp. 1049-1057. 2009. 9 (In Japanese) 近藤靖史、ほか 5 名: 断熱材の性能変化要因の検討と振動による断熱性能 変化の実験 建築用断熱材の長期断熱性能変化に関寸る研究（その 1)、日 本建築学会環境系論文集、第 74 巻、第 643 号、pp. 1049-1057、2009.9

4）須貝高、石田卓 : 高温・多湿状態での各種断熱材の寸法の変化および熱抵 抗の低下に関する実験的研究-繊維系断熱材とプラスチック系断熱材の比 較-。福岡大学工学集報, 第 76 号, pp. 153-167、2006. 3
5) Kondo, Y., et al. : EXPERIMENTS ON INFLUENCE OF MOISTURE ON THERMAL PERFORMANCE CHANGE OF INSULATIONS Long term thermal performance of building insulation materials Part 2. Journal of Environmental Engineering, Vol. 75, No. 649, pp. 261-269. 2010. 3 (In Japanese) 近藤靖史、ほか 5 名: 水分による断熱材の断熱性能変化に関する実験 建 築用断熱材の長期断熱性能変化に関する研究（その 2 ）、日本建築学会環境 系論文集、第 75 巻、第 649 号、pp. 261-269、2010. 3

6） JIS A 1486 : 発泡プラスチック系断熱材の熱抵抗の長期変化促進試験方 法、2014

7) ISO11561: Aging of thermal insulation materials - Determination of the longterm change in thermal resistance of closed-cell plastics (accelerated laboratory test methods) ISO. 1999

8) Blazejczyk, A. : Morphometric analysis of one-component polyurethane foams applicable in the building sector via X-ray computed microtomography. Materials, $11,1717,2018.9$

9）福田杉夫、ほか 3 名：外断熱防水工法における断熱材の性能評価（その 1 露出断熱防水法における屋外露出試験体および実現場品の熱的性能評価)、 日本建築学会大会学術講演梗概集 (九州)、pp. 727-728、2016. 8

10）北山大、新納敏文：防水層の通気性評価方法に関する研究（その 3 ） 子 くれ空間内部温湿度に関する実験的考察、日本建築学会大会学術講演梗概 集 (九州)、pp. 201-202，1998.9

11）久永真子、北垣亮馬、石田崇人：温冷繰返しによる発泡プラスチック系 断熱材 (XPS) の水分浸漬の分析、日本建築学会大会学術講演梗概集（東 北)、pp. 1393-1394.2018．9

12) 鎌形 慶二 : 膨潤度の測定法、日本ゴム協会誌、第 31 巻、第 11 号、 pp. 965-965、1958

13) Honma, Y., et al. : THE HYGROTHERMAL ENVIRONMRNT IN THE CRWAL SPACE INSULATED ON FOUNDATION WALL IN THE SUMMER INVOLVING RAINY SEASON Study on vertical edge insulation method for the moderate and humid climate region Part 2, Journal of Architecture Planning Environmental Engineering, No. 530, pp. 25-30, 2000. 4 (In Japanese) 本間義規、鈴木大隆、坂本雄三 : 梅雨時期を含む夏期の基礎断熱床下空間 の温湿度環境 温暖地における基盤断熱工法に関する研究 その 2 、日本 建築学会計画系論文集、第 530 号、pp. 25-30、2000. 4

14）大井一将、ほか 3 名：基礎断熱住宅における居住者行動が床下温湿度環 境に与える影響に関する研究、2017 年度日本建築学会、関東支部研究報 告、第 88 巻、pp. 33-36、2018. 3

15 ) JIS A 1412-2: 熱絶縁材の熱抵抗及び熱伝導率の 測定方法一第 2 部：熱流計法（HFM 法）、1999

16) JIS A 1475 : 建築材料の平衡含水率測定方法、2004

17) Kondo, Y., et al. : MEASUREMENTS AND NUMERICAL SIMULATIONS ON LONG TERM THERMAL PERFORMANCE OF PLASTIC INSULATION FOAMS, Journal of Environmental Engineering, Vol.73, No.634, pp. 1361-1368, 2008. 12 (In Japanese)

近藤靖史、ほか 3 名 : 発泡プラスチック系断熱材の長期断熱性能変化の測 定及び数值解析、日本建築学会環境系論文集、第 73 巻、第 634 号、pp. 1361-1368、2008. 12

[2020 年 6 月 2 日原稿受理 2020 年 9 月 4 日採用決定 $]$ 